\title{
Violência velada: Estratégia de conscientização e combate da violência contra o idoso em Governador Valadares, Minas Gerais
}

\author{
BLaís Ciribelli Yamaguchi, Rubens Correa Meirelles Junior, Gabriela Souza Fernandes, Marina
} Corrêa Lima, Waneska Alexandra Alves, Rayane Evelin Brito Marques

\section{Resumo}

O envelhecimento tem se destacado nas últimas décadas devido aos avanços na área da saúde que possibilitaram maior qualidade e expectativa de vida. O perfil de mortalidade brasileira tem passado por recentes mudanças, com a redução do número de óbitos por doenças infecto-parasitárias e aumento da prevalência de doenças crônico-degenerativas e causas externas. Dentre os agravos por causas externas, a violência contra o idoso merece atenção por ser subnotificada. O maior desafio das políticas destinadas a saúde da pessoa idosa está na divulgação e na operacionalização desses instrumentos, para que seja garantida a assistência integral aos idosos e a prevenção de atos de maus-tratos aos mesmo. Objetivou-se dialogar, orientar e conscientizar os idosos que frequentam o Serviço Social do Comércio (SESC) de Governador Valadares sobre o tema violência contra o idoso. Sob a perspectiva da concepção dialógica de Paulo Freire sobre educação em saúde, os ligantes da Liga Acadêmica de Saúde Coletiva (LASC) da Universidade Federal de Juiz de Fora, Campus Governador Valadares, propuseram uma atividade pautada em três momentos: a investigação temática - com a divisão dos participantes em dois grupos, cada grupo com 8 idosos, em que os eles compartilharam conhecimentos e vivências a respeito do tema; a descodificação concretizada na apresentação artística de um caso de violência contra o idoso discutido e encenado por cada grupo; e o fechamento teórico - em que os ligantes transmitiram informações, como as tipologias da violência, as definições e dados estatísticos regionais. Os tipos de violência mais retratados pelos idosos foram: abuso psicológico, exploração financeira, abandono e negligência. Apesar da Política Nacional do Idoso e do Estatuto do Idoso assegurarem legalmente dignidade e participação dessa população em sociedade, muitos participantes relataram dificuldade em denunciar os abusos, pois os principais agressores são os elementos familiares. A violência contra o idoso pode assumir várias formas e ocorrer em diferentes situações; e por diferentes motivos é subdiagnosticada. Entre as causas para o difícil diagnóstico estão os sentimentos da vítima de culpa e vergonha, medo de retaliação ou represália por parte do agressor, ou ainda receio de ser internada em asilo. A realização de uma atividade dinâmica e interativa possibilita uma troca de experiências, por meio de um diálogo horizontal, que garante a efetividade da prática de educação em saúde com a população idosa, além de ampliar o olhar dos ligantes, futuros profissionais da saúde, quanto à valorização da população idosa, que tende a aumentar nos próximos anos. Os maus-tratos contra idosos apresentam-se como um problema relevante para saúde pública. Medidas educativas e de mobilização social devem ser implementadas com o objetivo de esclarecer a esse grupo os seus direitos, orientar quanto à atitude apropriada a adotar diante da agressão, facilitar a denúncia e a obtenção de apoio ou ajuda para o problema e sua participação na construção de uma rede de proteção ao idoso.

Descritores: Saúde do Idoso; Violência; Educação em Saúde. 